\title{
Decreased levels of heat shock proteins in gut epithelial cells after exposure to plant lectins
} J H Ovelgönne, J F J G Koninkx, A Pusztai, S Bardocz, W Kok, S W B Ewen,
H G C J M Hendriks, J E van Dijk leaving these cells less well protected against the potentially harmful content of the gut lumen.

(Gut 2000;46:679-687)

Keywords: gut; rat small intestine; Caco-2 cells; lectins; stress proteins; heat shock proteins; heat shock

Living cells have a highly conserved response to adverse changes in their environmental conditions, commonly referred to as the heat shock response or stress response. Apparently a defensive mechanism, this response is elicited by a variety of physical and chemical agents, including heat shock, oxidising agents, heavy metals, sulphydryl reagents, anoxia, and ethanol. ${ }^{1-7}$ The most obvious characteristics of the stress response are overall inhibition of protein synthesis and enhanced synthesis of molecular chaperones, more commonly known as heat shock proteins (HSPs) or stress proteins. Exposure of cells to heat shock and other stressors results in virtual shutdown of normal cellular protein synthesis, parallelled by a shift to high levels of HSP synthesis. ${ }^{8}$ It is considered that induction of HSPs in mammalian cells is transcriptionally regulated. Transcription is initiated by a heat shock transcription factor. ${ }^{70-13}$ This protein is thought to be constitutively present ${ }^{14}$ and kept in an inactive state by its association with HSP70 in particular. ${ }^{15}$ During exposure to proteotoxic agents HSP70 is required to chaperone damaged proteins and consequently its association with the heat shock factor is broken. Subsequently the heat shock factor trimerises, migrates to the nucleus, and activates the promoters of heat shock genes. ${ }^{16}$ In addition to transcriptional regulation, translational regulation has been described in insect cells ${ }^{517}$ and there is some evidence for this type of regulation in mammalian cells. ${ }^{18} 19$

A large body of evidence links the stress response to a consequent decrease in cellular sensitivity to stress. It has been demonstrated that thermotolerance is conferred by increased levels of HSPs. This has been observed under conditions where HSPs are induced by environmental stress $^{52021}$ and by transfection of HSP genes. ${ }^{2-26}$ PHA-E $_{4}$ and WGA. However, after exposure to lectins, these cells were still capable of heat induced heat shock protein synthesis, and total protein synthesis was not impaired indicating specific inhibition of HSP synthesis in non-stressed cells. Conclusions-We conclude that PHA and WGA decrease levels of stress proteins in rat gut and enterocyte-like Caco- 2 cells,
Abbreviations used in this paper: PHA, Phaseolus vulgaris lectin; PHA- $\mathrm{E}_{4}$, Phaseolus vulgaris isolectin $\mathrm{E}_{4}$; WGA, wheat germ agglutinin; HSP, heat shock protein; BiP, binding protein; GlcNAc, $\mathrm{N}$-acetylglucosamine; LA, lactalbumin; DMEM, Dulbecco's modified Eagle medium; FCS, fetal calf serum. 
As a consequence of dietary intake, gut epithelial cells are regularly exposed to high levels of potentially harmful substances. Among these substances are the lectins which are contained in several foods of leguminous origin. At relatively high dietary intake lectins such as Phaseolus vulgaris lectin (PHA) and wheat germ agglutinin (WGA) can have harmful effects. Binding of lectins induces hyperplastic growth of the rat gut and pancreas, ${ }^{27-29}$ increased turnover of gut epithelial cells, ${ }^{30}{ }^{31}$ polymannosylation of the mucosal membranes of the small intestine, ${ }^{32}$ and alterations of the activities of brush border enzymes. ${ }^{33}$ In vitro, apparently as a result of lectin binding to the cell membrane, changes are induced in the cellular metabolism of enterocyte-like fully differentiated Caco-2 cells. ${ }^{34-35}$ Both in vitro ${ }^{34} 35$ 37-40 and in vivo ${ }^{27}{ }^{41}$ these lectins cause structural lesions in gut epithelial cells leading to severe disruptions in the integrity of the epithelial layer.

In the experiments presented in this study we focus on PHA and WGA. These substances have been described as potent growth factors for intestinal cells. ${ }^{27-29}$ To assess the physicochemical stress caused by exposure to these lectins, we first screened slides made from the jejunum of rats which had been experimentally exposed to PHA or WGA for expression of HSPs in gut epithelium using monoclonal antibodies. Secondly, we used differentiated Caco-2 cells which display characteristics of small intestinal enterocytes both structurally and functionally to investigate if the lectins also induced changes in the heat shock response of these cells. In particular, we examined the effect of both lectins on expression of HSPs and established its extent.

\section{Materials and methods}

LECTINS

WGA with specificity for $\mathrm{N}$-acetylglucosamine (GlcNAc) was isolated from wheat germ by affinity chromatography. Briefly, WGA solubilised at $\mathrm{pH} 5.0$ was heated at $60^{\circ} \mathrm{C}$ for 10 minutes and the supernatant fraction absorbed on to a column of immobilised GlcNAc. WGA was eluted from the column with $0.1 \mathrm{M}$ GlcNAc. ${ }^{42}$ PHA with specificity for complex glycosyl side chains was isolated from red kidney beans by affinity chromatography on fetuin Sepharose-4B. ${ }^{43}$ WGA and Phaseolus vulgaris isolectin $\mathrm{E}_{4}$ (PHA- $\mathrm{E}_{4}$ ), when used in cell culture experiments, were from E-Y Laboratories (San Mateo, California, USA).

ANIMALS AND DIETS

Six male, conventionally grown specific pathogen free inbred Hooded-Lister rats of the Rowett colony, kept singly in metabolism cages, were prefed for three days (6 g/rat/day) on a semisynthetic, good quality diet consisting mainly of maize starch, potato starch, and glucose. This diet contained $10 \%(\mathrm{w} / \mathrm{w})$ lactalbumin (LA diet) as the sole protein. ${ }^{27}$ Rats weighing 80-90 $\mathrm{g}$ were divided into three groups of two rats each and pair-fed on different experimental diets for 10 days. The control group was kept on the same LA diet used for prefeeding. The WGA and PHA groups were fed diets based on the LA control diet in which $7 \%(\mathrm{w} / \mathrm{w})$ of the lactalbumin was replaced by an equal amount of either WGA or PHA (93 g lactalbumin with $7 \mathrm{~g}$ WGA or PHA per $\mathrm{kg}$ diet). The food intake of all three groups was restricted to the voluntary intake of the PHA group (6 g diet/rat/day). This amount of diet contained $42 \mathrm{mg} /$ day of WGA or PHA. On the morning of the 10th day, after overnight fasting, rats were offered $2 \mathrm{~g}$ of their respective diets and killed under ether anaesthesia two hours later. The abdomen was cut open and two gut sections of $2 \mathrm{~cm}$ each, $7 \mathrm{~cm}$ from the pylorus, were taken for histology and HSP immunostaining.

TISSUE PROCESSING FOR HISTOLOGY AND HSP IMMUNOSTAINING

Small intestinal segments, $2 \mathrm{~cm}$ in length, were fixed in $0.1 \mathrm{M}$ phosphate buffered $4 \%$ formalin, $\mathrm{pH} 7.3$, for 24 hours. After dehydration and embedding in paraffin, sections of $5 \mu \mathrm{m}$ were cut.

After deparaffination, sections were incubated with monoclonal antibodies against HSPs and subsequently processed with an avidin/biotin/peroxidase staining kit (Vectastain, Vector Laboratories, Burlingname, California, USA). Endogenous peroxidase activity was blocked by exposure to methanolhydrogen peroxidase for 15 minutes. In addition, the sections were counterstained with haematoxylin. The staining intensity of 20 well oriented crypts and villi per rat was estimated semiquantitatively. Estimations were performed at positions 10 villi apart from each other.

The specificity of the immunostaining was controlled by omitting the primary antibody, the secondary antibody, or the substrate. The specificity for the HSPs of the pattern showing lightly stained crypts and heavily stained villi was verified by incubating sections from lectin treated and control rat gut with an antiserum directed against actin. These sections stained homogeneously in all cases.

Monoclonal antibodies against HSP60, HSP70, HSP72, BiP, and HSP90 were purchased from Stressgen Biotechnologies Corporation, Victoria, British Columbia, Canada (product numbers: SPA 800, SPA 806, SPA 810, SPA 822, and SPA 830, respectively) and processed according to the manufacturer's instructions.

CELL CULTURE

The cell line Caco-2 was established from a moderately well differentiated colon adenocarcinoma. Caco-2 cells were routinely grown in Dulbecco's modified Eagle's medium (DMEM) (Flow Laboratories, Amsterdam, Netherlands). The medium was supplemented with $1 \%$ non-essential amino acids (Flow), $50 \mu \mathrm{g} / \mathrm{ml}$ gentamicin (Flow), $10 \mathrm{mM}$ sodium bicarbonate, $25 \mathrm{mM}$ HEPES, and $20 \% \mathrm{v} / \mathrm{v}$ fetal calf serum (FCS) (Sanbio, Uden, Netherlands) at $37^{\circ} \mathrm{C}$ with $5 \% \mathrm{CO}_{2}$. Cells were seeded at 40000 cells $/ \mathrm{cm}^{2}$ in six well tissue culture plates $\left(10 \mathrm{~cm}^{2}\right)$ (Greiner, Alphen a/d Rijn, Nether- 

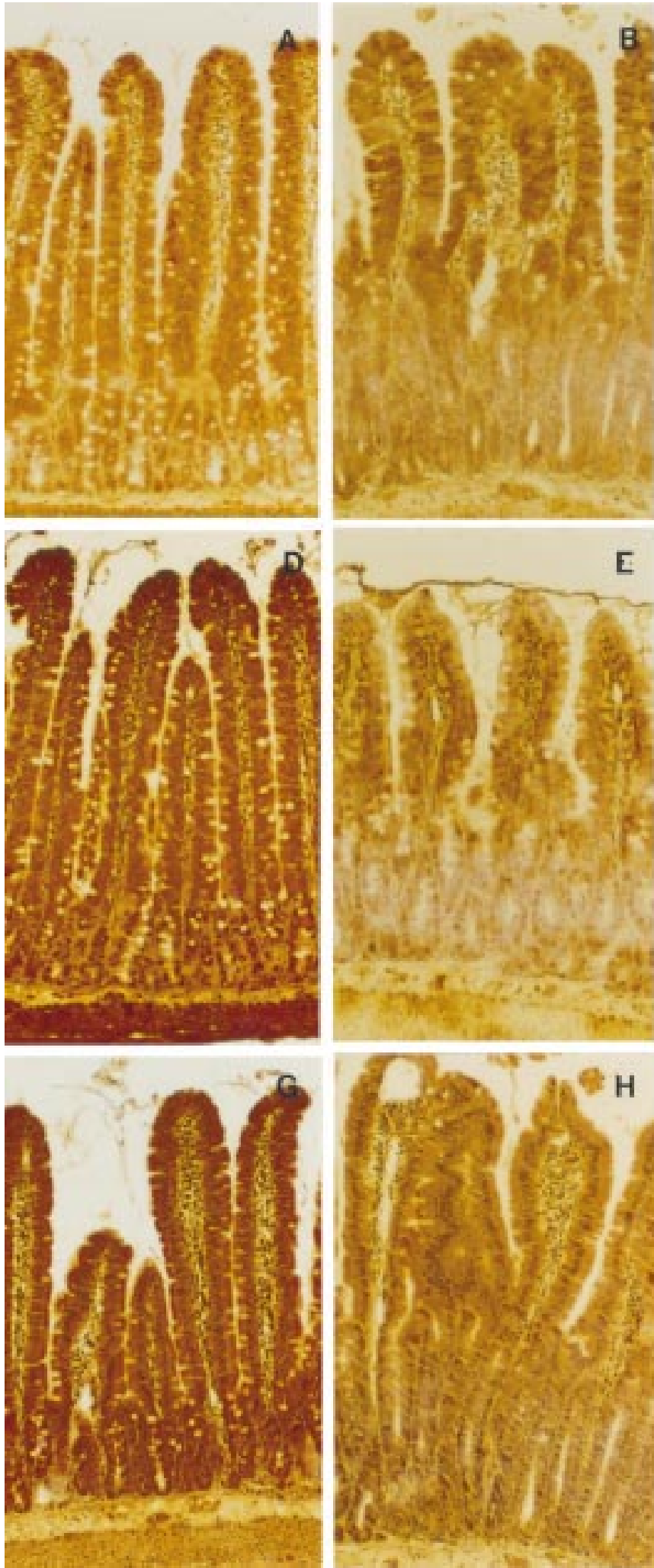

Figure 1 Sections of the jejunum from rats fed diets containing lactalbumin (control), phytohaemagglutinin (PHA), or wheat germ agglutinin (WGA) stained with monoclonal antibodies to HSP70, $H S P 72$, and $H S P 90$. The jejunal sections of rats fed lactalbumin $(A, D, G), P H A(B, E, H)$ or $W G A(C, F, I)$ are shown. Sections $A, B$, and $C$ were stained with the antibody to HSP70, sections D, E, and F with the antibody to HSP72, and sections $G, H$, and $I$ with the antibody to HSP90.

lands). Cells were cultured for 19 days to achieve fully differentiated cell populations. Culture medium was changed three times a week.
For incubation with lectin, cells were incubated in medium without serum in order to be free from potentially reactive carbohydrates. Medium was first replaced with culture me- 
Table 1 Intensity of immunostaining of the jejunal crypts and villi from rats fed on diets containing lactalbumin (LA), phytohaemagglutinin (PHA), or wheat germ agglutinin (WGA)

\begin{tabular}{llll}
\hline Heat shock protein & Lectin & $\begin{array}{l}\text { Staining intensity of the } \\
\text { crypt }\end{array}$ & $\begin{array}{l}\text { Staining intensity of the } \\
\text { villus }\end{array}$ \\
\hline HSP70 & LA PHA WGA & +++++++ & +++++++++ \\
HSP72 & LA PHA WGA & ++++++++ & ++++++++ \\
HSP90 & LA PHA WGA & +++++++ & +++++++ \\
& & +++++++++++
\end{tabular}

The sections of the jejunum were stained with monoclonal antibodies to HSP70, HSP72, and HSP90. The intensity of the immunostaining of PHA and WGA fed rats was matched with the staining intensity of the corresponding LA fed rats. Based on this comparison the intensity of the staining was scored using an arbitrary semiquantitative scale (strong staining ++++ , moderate staining +++ , weak staining ++ , very weak staining + ).

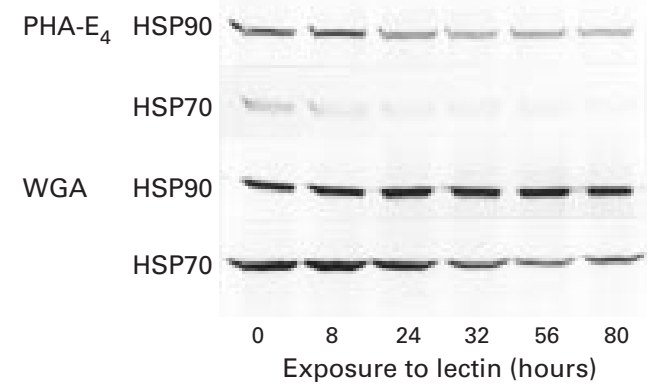

Figure 2 Inhibition of HSP70 and HSP90 synthesis in differentiated Caco-2 cells during incubation with lectins. Cells were exposed for 0 (control), 8, 24, 32, 56, and 80 hours to either $100 \mu \mathrm{g} / \mathrm{ml}$ of $\mathrm{PHA}-\mathrm{E}_{4}$ or $\mathrm{WGA}$.

Subsequently the cells were processed for western blotting and immunostaining as described.

dium containing $10 \%$ FCS and $1 \%$ serum substitute Ultroser G (Gibco Europe, Hoofddorp, Netherlands) on day 14 after cell seeding. Two days later medium containing $1 \%$ FCS and $2 \%$ Ultroser $\mathrm{G}$ was substituted for the previous one. On day $19, \mathrm{PHA}_{4} \mathrm{E}_{4}$ or WGA was added to the cells by replacing the medium with $1 \mathrm{ml}$ of DMEM containing $100 \mu \mathrm{g} / \mathrm{ml}$ of lectin. Incubation of the cells with the lectins was performed in triplicate for 48 hours. Exposure to lectins was continued with those cells receiving a heat shock. In these Caco-2 cells incubation with lectins was prolonged for the duration of the heat shock (one hour) and recovery period (six hours).

Heat shocks were applied by placing the culture dishes in water heated by a circulating Thermomix 1419 (Braun AG, Melsungen, Germany) which provided a stable temperature to within $0.1^{\circ} \mathrm{C}$ (SE). Under these conditions temperature equilibration of the cells was achieved in about 30 seconds.

DNA AND PROTEIN SYNTHESIS IN DIFFERENTIATED CACO-2 CELLS AFTER EXPOSURE TO LECTINS Exposure of the cells to WGA and $\mathrm{PHA}-\mathrm{E}_{4}$ was performed in quadruplicate in $0.5 \mathrm{ml}$ of DMEM containing $100 \mu \mathrm{g} / \mathrm{ml}$ of WGA or

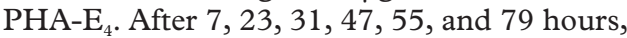
$100 \mu \mathrm{l}$ of DMEM containing $0.05 \mu \mathrm{Ci}$ of $\left[2-{ }^{14} \mathrm{C}\right]$ thymidine (Amersham Nederland, s-Hertogenbosch, Netherlands) and $2 \mu \mathrm{Ci}$ of L- $\left[\right.$ methyl $\left.-{ }^{3} \mathrm{H}\right]$ methionine (Amersham) were added to the monolayer and incubation was continued for another hour. Adding $1 \mathrm{ml}$ of $10 \%(\mathrm{w} / \mathrm{v})$ trichloroacetic acid $\left(0^{\circ} \mathrm{C}\right)$ to the monolayer stopped incorporation of the radioactive precursors. Subsequently, the monolayer was washed three times with $1 \mathrm{ml}$ of $0.01 \mathrm{M}$ PBS (0.01 M Na $\mathrm{HPO}_{4}, 0.01 \mathrm{M} \mathrm{NaH} \mathrm{PO}_{4}$, $0.9 \%(\mathrm{w} / \mathrm{v}) \mathrm{NaCl}) \mathrm{pH} 7.3$, fixed with $1 \mathrm{ml}$ of methanol for 10 minutes, and finally dissolved in $0.5 \mathrm{ml}$ of $0.1 \mathrm{M} \mathrm{NaOH}$. The incorporated radioactivity present in $0.2 \mathrm{ml}$ of $0.1 \mathrm{M} \mathrm{NaOH}$ was determined by liquid scintillation counting in $2 \mathrm{ml}$ of Dynagel (J T Baker Chemicals, Deventer, Netherlands).

Incorporation of $\left[2-{ }^{14} \mathrm{C}\right]$ thymidine and L- $\left[\right.$ methyl $\left.-{ }^{3} \mathrm{H}\right]$ methionine by differentiated Caco-2 cells was also studied after exposure of the cells to $100 \mu \mathrm{g}$ of heat inactivated WGA and PHA-E $\mathrm{E}_{4}$. Inactivation of the lectins was accomplished by heating the lectins for 60 minutes at $100^{\circ} \mathrm{C}$.

Incorporated radioactivity, calculated as disintegrations per minute per $\mu \mathrm{g} \mathrm{DNA}^{44}$ was expressed as relative incorporation (factor by which incorporation was decreased or increased compared with cell cultures that were

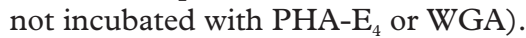

Trypan blue exclusion ${ }^{45}$ was used to determine the effect of the lectins on cell viability. The cell monolayer was stained with $0.2 \%$ (w/v) trypan blue in $0.01 \mathrm{M} \mathrm{PBS,} \mathrm{pH} 7.3$, for five minutes. After decanting the dye cell counts of stained and dye excluding cells were made in situ.

WESTERN BLOT ANALYSIS

Cells from each well were solubilised in sample buffer ${ }^{46}$ containing $125 \mathrm{mM}$ tris(hydroxymethyl) aminomethane $\mathrm{HCl}, 4 \%$ SDS, $10 \%$ $\beta$-mercaptoethanol, $20 \%$ glycerol, and $0.0015 \%$ bromophenol blue, $\mathrm{pH}$ 6.8. Separa-
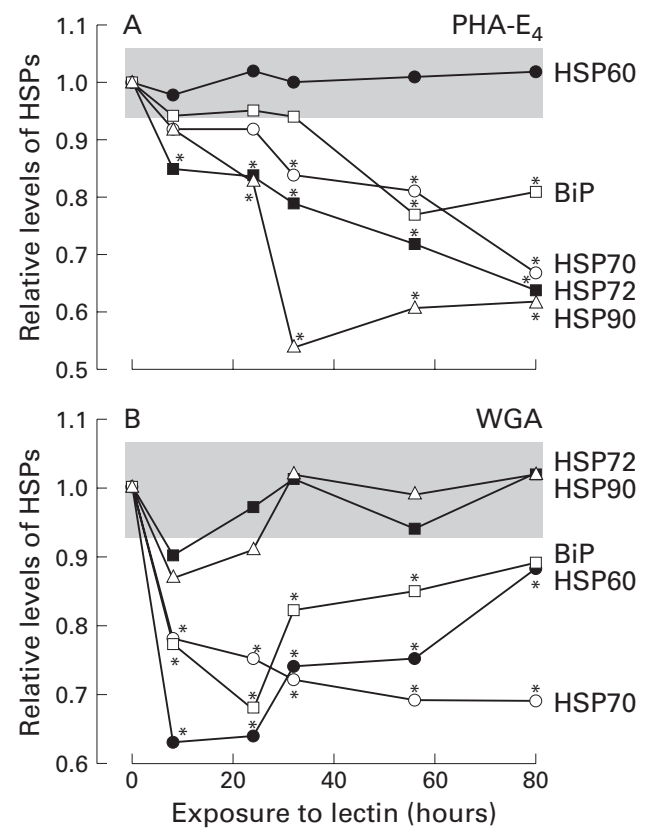

Figure 3 Inhibition of HSP synthesis in differentiated Caco-2 cells during incubation with lectins. Cells were exposed for various times to either $100 \mu \mathrm{g} / \mathrm{ml}$ of $\mathrm{PHA}-E_{4}$ or WGA. Subsequently, after 0, 8, 24, 32, 56, and 80 hours cells were processed for western blotting and immunostaining as described. The effect of $\mathrm{PHA}-\mathrm{E}_{4}(A)$ and WGA (B) on the relative levels of HSPs was determined using two cell passages and quadruplicate cultures per passage. Significant differences $\left({ }^{*} p<0.05\right)$ between the relative levels of HSPS of lectin exposed and control Caco-2 cells are indicated. 

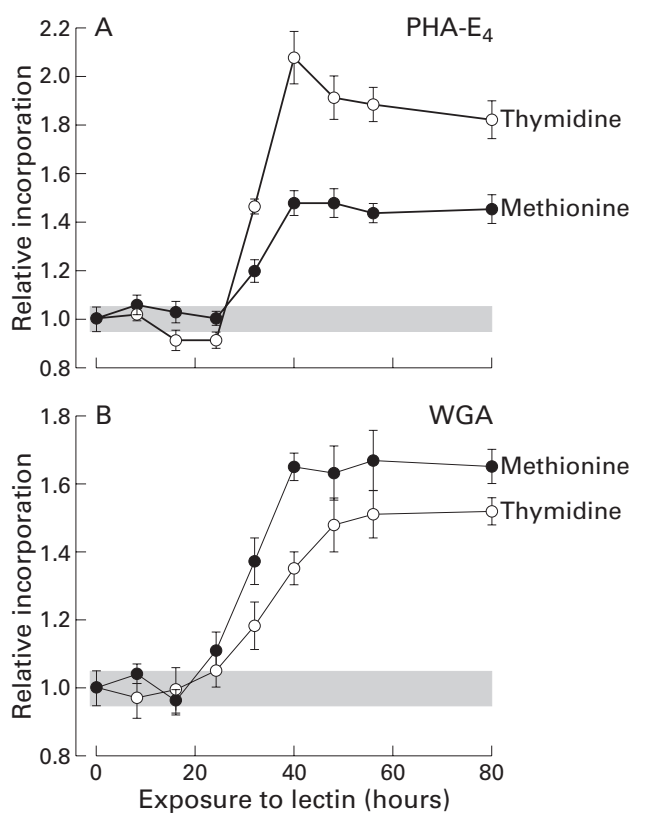

Figure 4 Relative incorporation of precursors for DNA and protein synthesis by differentiated Caco-2 cells after incubation with lectins. At various points (0, 8, 16, 24, 32, 40, 48, 56, and 80 hours) after lectin exposure to either 100 $\mu \mathrm{g} / \mathrm{ml}$ of $\mathrm{PHA}-\mathrm{E}_{\mathrm{A}}(\mathrm{A})$ or $\mathrm{WGA}(\mathrm{B})$ relative incorporation of $\left[2-{ }^{14} \mathrm{C}\right]$ thymidine and $\mathrm{L}-\left[\right.$ methyl $\left.-{ }^{3} \mathrm{H}\right]$ methionine was established using two cell passages and quadruplicate cultures per passage. Incorporated radioactivity, calculated as disintegrations per minute per $\mu \mathrm{g} D N A,{ }^{44}$ was expressed as relative incorporation (factor by which incorporation was decreased or increased compared with cell cultures that were not incubated with $P H A-E_{4}$ or $\left.W G A\right)$. Results are expressed as mean (SD) relative incorporation. The shaded area represents the mean (SD) relative incorporation of cell cultures not incubated with lectins.

tion of proteins was performed by polyacrylamide gel electrophoresis ( $10 \%$ gels). ${ }^{46}$ Samples were adjusted for equal amounts of protein. ${ }^{47}$ Subsequently, proteins were transferred to Immobilon-P PVDF membranes following the recommendations of the manufacturer (Millipore, Bedford, USA). HSPs were detected using monoclonal antibodies purchased from Stressgen (Victoria, British Columbia, Canada) and a peroxidase coupled detection system (Bio-Rad, Hercules, California, USA). Quantification of stained blots was performed on a Bio-Rad GS700 imaging densitometer.

To assess statistical significance between the quantified staining intensities of control Caco-2 cells and cells not exposed to lectins, analysis of variance with comparison of means

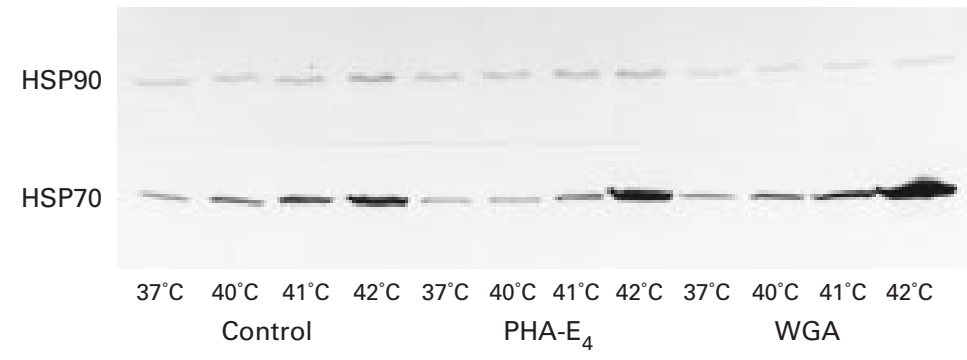

Figure 5 Heat shock induced synthesis of HSP70 and HSP9O in differentiated Caco-2 cells after preincubation with lectins. After lectin exposure for 48 hours to either $100 \mu \mathrm{g}$ of $\mathrm{PHA}-\mathrm{E}_{4}$ or $\mathrm{WGA}$, the cells were heat shocked for one hour at $37^{\circ} \mathrm{C}$ (control), $40^{\circ} \mathrm{C}, 41^{\circ} \mathrm{C}$, or $42^{\circ} \mathrm{C}$ and allowed to recover for six hours. During the subsequent heat shock and recovery period, lectin exposure was continued. After these experimental procedures the cells were processed for western blotting and immunostaining as described. was used. Statistical significance was accepted at $\mathrm{p}<0.05$.

\section{Results}

HSP CONTENT OF RAT GUT TISSUE

Gut tissue sections from rats fed lactalbumin (fig 1A, D, G) had a normal appearance. The villus-crypt ratio of the jejunum of these rats was about 4 . There were striking changes in the morphology of the rat small intestine when rats were fed the lectin containing diet. The crypts of the jejuni of rats fed on diets containing PHA (fig 1B, E, H) or WGA (fig 1C, F, I) were elongated whereas the length of the villi was only slightly reduced. These gut tissue sections showed a villus-crypt ratio of 1-2. In addition, the hyperregenerative crypts displayed much higher mitotic activity compared with controls (data not shown).

Semiquantitative evaluation of the staining intensities is presented in table 1 . The intensity of the anti-HSP immunostaining in rats fed the control diet, which represents the constitutive levels of HSPs, was equally strong in the whole section (fig 1A, D, G; table 1). In comparison with the gut sections stained with anti-HSP72 (fig 1D) and anti-HSP90 (fig 1G), the staining intensity of the control section with antiHSP70 (fig 1A) was weaker.

Compared with the jejunal crypts of lactalbumin fed rats (fig 1A, D, G; table 1) the HSP content of the intestinal cells in the hyperregenerative crypts of PHA fed (fig $1 \mathrm{~B}, \mathrm{E}, \mathrm{H}$; table 1) and WGA fed (fig 1C, 1F, I; table 1) rats was decreased considerably. Also, the villi of these gut sections showed weaker intensity of anti-HSP immunostaining (fig $1 \mathrm{~A}-\mathrm{F}$; table 1 ). The strongest reduction in staining intensity was seen in the villi of rats fed PHA after immunostaining with anti-HSP72 (fig 1E) and anti-HSP90 (fig $1 \mathrm{H}$ ), and also in rats fed WGA after immunostaining with anti-HSP90 (fig 1I). A decrease in the immunostaining intensity could not be found when rats were fed heat inactivated $\left(60\right.$ minutes at $100^{\circ} \mathrm{C}$ ) lectins (data not shown).

HSP CONTENT OF DIFFERENTIATED CACO-2 CELLS DURING LECTIN EXPOSURE

The lectins PHA-E $\mathrm{E}_{4}$ and WGA were used to determine the effect of lectin exposure on HSP synthesis in differentiated Caco- 2 cells. The cellular content of HSP70 and HSP90 is given in fig 2, quantification of which and three other HSPs (HSP60, HSP72, and BiP) are given in fig 3. The results obtained from control Caco-2 cells clearly demonstrate that constitutive levels of HSPs are present in these enterocyte-like cells.

In general, the relative content of HSPs of non-proliferating differentiated Caco-2 cells decreased in time during exposure to $100 \mu \mathrm{g} / \mathrm{ml}$ of PHA-E $\mathrm{E}_{4}$ or WGA. The western blot (fig 2) clearly demonstrated an inhibitory

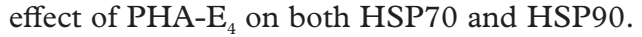
In contrast, WGA interfered only with the relative content of HSP70. This lectin has little or no effect on HSP90 content.

A striking difference was apparent between PHA- $\mathrm{E}_{4}$ and WGA with respect to their effects 
on HSP synthesis (fig 3). With the exception of HSP60, levels of all other proteins decreased in time during exposure to PHA-E $\mathrm{E}_{4}$. HSP60 was different in that its cellular level remained unchanged over time during lectin exposure. In contrast, WGA caused an initial decrease in the levels of HSPs during the first 24 hours of exposure. This increase (except for HSP70) was followed by partial (HSP60 and BiP) or complete (HSP70 and HSP90) recovery of the HSP content of the cells.

To determine if inhibition of HSP synthesis by lectins was caused by an overall decrease in cellular protein synthesis, differentiated Caco- 2 cells were pulse labelled for four hours with methionine at various times after the start of lectin exposure. During the first 24 hours of exposure, relative incorporation did not change. However, at selected points hereafter both PHA- $\mathrm{E}_{4}$ and WGA appeared to stimulate
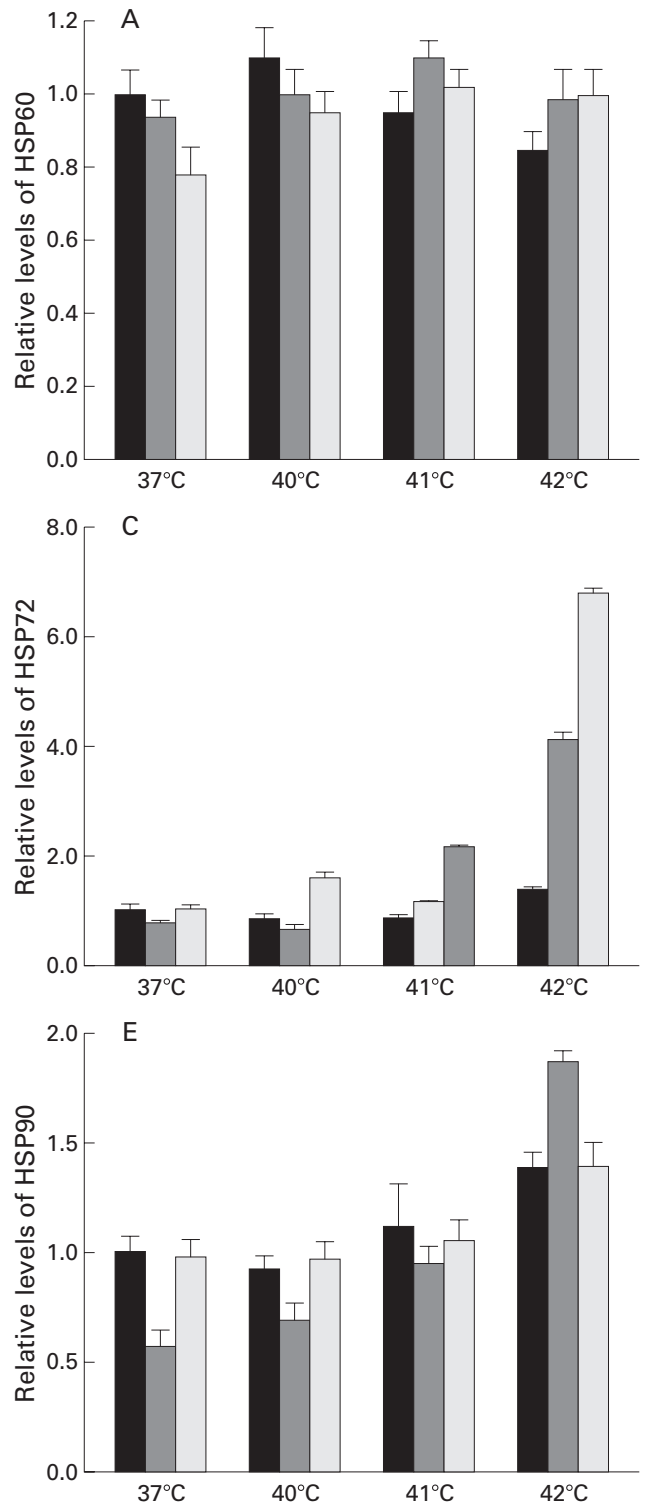

relative incorporation of methionine (fig 4). From this experiment it is obvious that the cellular protein synthesis machinery was not inhibited. The incorporation curve for DNA synthesis ran parallel to that of the protein.

Incubation of Caco-2 cells with $100 \mu \mathrm{g} / \mathrm{ml}$ of PHA- $\mathrm{E}_{4}$ in the presence of $1 \mathrm{mg} / \mathrm{ml}$ of fetuin or $100 \mu \mathrm{g}$ of WGA in the presence of $0.1 \mathrm{M}$ GlcNAc failed to induce the observed changes in HSP synthesis (data not shown).

\section{HSP RESPONSE IN LECTIN EXPOSED}

DIFFERENTIATED CACO-2 CELLS

To investigate if the heat shock response in lectin exposed differentiated Caco-2 cells was impaired after lectin preincubation, these cells were subsequently heat shocked for one hour $\left(40^{\circ} \mathrm{C}, 41^{\circ} \mathrm{C}\right.$, and $\left.42^{\circ} \mathrm{C}\right)$ and allowed to recover for six hours at $37^{\circ} \mathrm{C}$. During heat shock and the recovery period, lectin exposure was
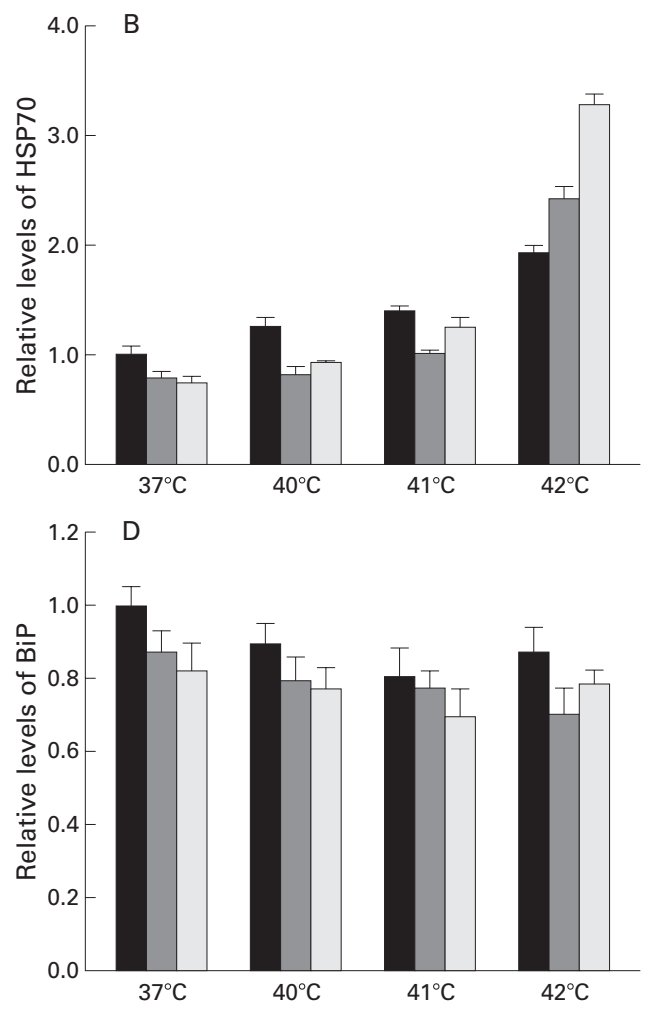

exposed $\rightarrow$ heat shock

PHA- $\mathrm{E}_{4}$ exposed $\rightarrow$ heat shock WGA exposed $\rightarrow$ heat shock

Figure 6 HSP synthesis in differentiated Caco-2 cells after preincubation with lectins. Cells were exposed for 48 hours to either $100 \mu \mathrm{g} / \mathrm{ml}$ of $\mathrm{PHA}-E_{4}$ or $\mathrm{WGA}$ and subsequently heat shocked for one hour at $37^{\circ} \mathrm{C}$ (control), $40^{\circ} \mathrm{C}, 41^{\circ} \mathrm{C}$, or $42^{\circ} \mathrm{C}$. The cells were allowed to recover for six hours. Lectin exposure was continued for the duration of the heat shock and recovery period. After these experimental procedures the cells were processed for western blotting and immunostaining as described. Two different cell passages were used to establish the effect of $\mathrm{PHA}-\mathrm{E}_{4}$ and $\mathrm{WGA}$. For each passage the relative levels of HSP6O (A), HSP70 (B), HSP72 (C), BiP (D), and HSP90 (E) were determined using triplicate cultures. 
continued. HSP responses of HSP70 and HSP90 are given in the western blot in fig 5 . Quantification of these and another three proteins (HSP60, HSP72, and BiP) is given in fig 6.

Heat shock did not induce all five HSPs. The heat shock response of control Caco-2 cells appeared to be restricted to HSP70, HSP72, and $\mathrm{HSP} 90$ (figs $5,6 \mathrm{~B}, \mathrm{C}, \mathrm{E}$ ). At $42^{\circ} \mathrm{C}$ the strongest induction was achieved for these proteins. Heat shock caused little or no change in induction of HSP60 or BiP (fig 6A, D).

In PHA-E $\mathrm{E}_{4}$ exposed cells relative levels of HSP70, HSP72, and HSP90 decreased when cells received a heat shock at $40^{\circ} \mathrm{C}$ and $41^{\circ} \mathrm{C}$. However, at $42^{\circ} \mathrm{C}$ significant induction of these proteins took place compared with the relative levels of control $\left(37^{\circ} \mathrm{C}\right)$ and heat shocked cells $\left(42^{\circ} \mathrm{C}\right)$. The effect on the relative levels of HSPs in WGA exposed cells was slightly different. HSP72 in particular was already induced at $40^{\circ} \mathrm{C}$ in WGA exposed cells. Another important observation is that in general, heat shock induced a stronger response in WGA exposed cells.

Western blots (fig 5) and their quantification (fig 6) clearly showed that differentiated Caco-2 cells which were preincubated with $\mathrm{PHA}^{-\mathrm{E}_{4}}$ and WGA were still capable of synthesising HSPs after heat treatment at $42^{\circ} \mathrm{C}$ and to a lesser extent at $41^{\circ} \mathrm{C}$. It is obvious from our results that the heat shock response in lectin preincubated differentiated Caco- 2 cells was not impaired. Interestingly, enhancement of the heat shock response was observed for HSP70, HSP72, and HSP90.

\section{Discussion}

Cells have a highly conserved set of stress proteins (HSPs) $)^{1-9}$ which are involved in coping with chemical or physical damage. Our data clearly demonstrated that lectins, which are known to cause structural lesions in gut epithelial cells on exposure, interfere with the levels of HSPs in these cells. The HSP content in the crypt cells of the jejunum of PHA and WGA fed rats was dramatically decreased compared with the jejunum of lactalbumin fed rats (fig 1).

It could be argued that decreased levels of HSPs in these hyperregenerative crypts (fig 1B, $\mathrm{C}, \mathrm{E}, \mathrm{F}, \mathrm{H}, \mathrm{I}$ ), which showed weaker intensity of anti-HSP60, HSP70, and HSP90 immunostaining, were caused by dilution of HSPs in the strongly dividing crypt cells. This observation was studied further in cultures of confluent non-proliferating differentiated Caco-2 cells. ${ }^{39}$ In general, the relative content of HSPs decreased during exposure to $\mathrm{PHA}_{-} \mathrm{E}_{4}$ and WGA (figs 2, 3). WGA induced decreases recovered during the experiment. Only HSP60 levels remained unchanged during exposure to PHA-E $\mathrm{E}_{4}$. As there is little or no mitotic activity in the cultures used, ${ }^{39}$ dilution of HSPs into progeny cells cannot account for the decrease in HSP content. Therefore, this finding strongly suggests that increased mitotic activity was not responsible for the decrease in HSP levels.
The stress response is often associated with transient inhibition of the rate of total protein synthesis in cells. ${ }^{898}$ We investigated if alterations in the rate of protein synthesis in PHA-E or WGA exposed cells could explain the observed depression of HSP levels (fig 4). Lectins do not interfere with protein synthesis during the first 24 hours of exposure. At later times the rate of protein synthesis in lectin exposed cells was even increased compared with control cells. These findings demonstrate that lower levels of HSPs in lectin exposed differentiated Caco- 2 cells (figs 2, 3) do not result from an overall decrease in the rate of cellular protein synthesis.

The heat shock response in lectin exposed cells does not appear to be impaired by lectin incubation. Cells preincubated with $\mathrm{PHA}-\mathrm{E}_{4}$ or WGA were still capable of synthesising HSPs (figs 5,6 ). When these cells were heat treated, levels of HSP70, HSP72, and HSP90 well exceeded the levels in heat shocked cells. Particularly at $42^{\circ} \mathrm{C}$, the overshoot of HSP synthesis was conspicuous. This phenomenon resembles sensitisation which can occur during complex exposures to heat $^{49}$ or sodium arsenite $^{50}$ and may indicate the presence of sublethal damage to the cell.

The thymidine incorporation experiments suggest that prolonged incubation (24 hours or longer) with lectins stimulates DNA synthesis (fig 4). As cell viability remains relatively constant (>96\%) and the DNA content per well does not change significantly during lectin exposure (data not shown), the change in thymidine incorporation most probably does not reflect increased DNA synthesis. Whether increased DNA repair occurs in these cells or whether the lectins interfere with nucleic acid metabolism in other ways is not known. Thymidine incorporation parallelled protein synthesis.

To withstand tissue damage by noxious components in the gut lumen, intestinal cells have evolved protective mechanisms. HSPs can be expected to play a pivotal role in this protection. To immediately cope with cell damage this tissue would benefit from high basal levels of HSPs. A high basal level of HSP72, the stress inducible form of HSP70, has been detected by western blot analysis in samples from rat colon. ${ }^{51}$ High basal levels of HSPs and induction of two novel HSPs by heat shock have been demonstrated in human oesophageal epithelium. ${ }^{52}$ From the intensity of the anti-HSP immunostaining in the enterocytes of rats fed the lactalbumin diet it can be judged that high constitutive levels of HSP70, HSP72, and HSP90 are present in this tissue (fig 1A, D, G). By western blotting of samples from Caco-2 cells not exposed to lectins, we have revealed constitutive expression of HSPs (figs 2, 3, 5).

The mechanism by which HSP levels in rat gut cells and enterocyte-like Caco- 2 cells are lowered by exposure to lectins is not apparent from our experiments. As synthesis of inducible HSPs following heat shock was not impaired by exposure to lectins (fig 6), levels of constitutive HSPs could be downregulated selectively. The speed of this downregulation suggests an active process. It is possible that 
HSPs are consumed in repairing sublethal cell damage without being adequately replenished. Lectins are known to interfere with the cytoskeleton of gut cells. Cytoskeletal lesions in rat enterocytes have been observed ${ }^{27}{ }^{41}$ and a shift in the ratio of globular to filamentous actin could be measured in differentiated Caco-2 cells. ${ }^{37}{ }^{39}$ This depolymerisation of the actin filaments takes place within a few minutes after the onset of lectin exposure. Studies on the function of HSP70 ${ }^{53}$ and HSP90 $0^{54}$ demonstrated actin binding activity by these proteins, which stabilises the actin filaments by cross linking. After lectin exposure, HSPs may be directed to the stabilisation of the cytoskeleton as well as the chaperoning of cellular proteins. If the resulting demand for HSPs is not met by adequate synthesis, levels of soluble HSPs decrease.

It has been shown that binding of lectins to their specific sugar reactive sites on the apical membranes of enterocytes, being a prerequisite to exert its effect on the cell, is the first step in the damage caused by these dietary components. Whereas PHA- $\mathrm{E}_{4}$ inhibits the heat shock response in gut epithelial cells (figs 1-3), PHA- $\mathrm{L}_{4}$ is an activator of the stress response in lymphocytes, ${ }^{55-57}$ acting by binding to lectin specific receptors on the cell membrane.

Considering the amount of evidence linking HSP levels to increased resistance to stress, it is likely that the lectins PHA-E $\mathrm{E}_{4}$ and WGA are detrimental not only to gut intestinal cells by damaging their apical membranes. Depression of the amounts of stress proteins in enterocytes by these lectins may leave the cells more vulnerable to exposure to agents produced by the digestive tract as well as to harmful agents of dietary origin. Considering that pathogenic bacteria such as Salmonella enteritidis and Escherichia coli induce stress proteins in intestinal cells ${ }^{58}$, lectin induced downregulation of these proteins may also indicate increased cellular susceptibility to bacterial invasion.

The Commission of European Communities supported this collaborative work. It was an European COST Action 98 programme coordinated by Dr A Pusztai.

1 Burdon RH. Heat shock and the heat shock proteins. Biochem f 1986;240:313-24

2 Morimoto RI, Tissières A, Georgopoulos C, eds. Stress proteins in biology and medicine. Cold Spring Harbour: Cold Spring Harbour Laboratory Press, 1990.

3 Schlesinger MJ. Heat shock proteins. f Biol Chem 1990;265: 12111-14.

4 Hightower LE. Heat shock, stress proteins, chaperones and proteotoxicity. Cell 1991;66:191-7.

5 Nover L. Heat shock response. Boca Raton: CRC Press, 1991.

5 Nover L. Heat shock response. Boca Raton: CRC Press, 1991. Welch WJ. Mammalian stress response: Cell physiology,
structure/function of stress proteins, and implications for structure/function of stress proteins, and implications
medicine and disease. Physiol Rev 1992;72:1063-75.

7 Morimoto RI, Tissieres A, Georgopoulos C, eds. The biology of heat shock proteins and molecular chaperones. Cold Spring Harbour: Cold Spring Harbour Laboratory Press, 1994.

8 Koninkx JFJG. Protein synthesis in salivary glands of Drosophila hydei after experimental gene induction. Biochem f 1976;158:623-8.

9 Ovelgönne H, Bitorina M, van Wijk R. Stressor specific activation of heat shock genes in $\mathrm{H} 35$ rat hepatoma cells. Toxicol Appl Pharmacol 1995;135:100-9.

10 Wu C. The 5' ends of Drosophila heat shock genes in chromatin are hypersensitive to DnaseI. Nature 1980;286:85460 .

$11 \mathrm{Wu}$ C. Two protein-binding sites in chromatin implicated in the activation of heat-shock genes. Nature 1984;309:229the actir.

12 Lis J, Wu C. Protein traffic on the heat shock promoter: parking, stalling and trucking along. Cell 1993;74:1-4.

13 Morimoto RI. Cells in stress: Transcriptional regulation of heat shock genes. Science 1993;259:1409-10.
14 Zimarino V, Wu C. Induction of sequence-specific binding of Drosophila heat shock activator protein without protein of Drosophila heat shock activator p
synthesis. Nature 1987;327:727-30.

15 Abravaya K, Myers MP, Murphy SP, et al. The human HSP hsp70 interacts with HSF, the transcription factor that regulates heat shock gene expression. Genes Dev 1992;6: 1153-64.

16 Sarge KD, Murphy SP, Morimoto RI. Activation of heat shock gene transcription by heat shock factor 1 involves oligomerization, acquisition of DNA-binding activity, and nuclear localization and can occur in the absence of stress. Mol Cell Biol 1993;13:1392-407.

17 DiDomenico BJ, Bugaisky GE, Lindquist S. Heat shock and recovery are mediated by different translational mechanisms. Proc Natl Acad Sci USA 1982;79:6181-5.

18 De Benedetti A, Joshi-Barve S, Rinker-Schaffer C, et al. Expression of antisense RNA against initiation factor eIF-4E mRNA in HeLa cells results in lengthened cell division times, diminished translation rates and reduced division times, diminished translation rates and reduced levels of both eIF-4E and the p 2 Cell Biol 1991:11:5435-45.

19 Joshi-Barve S, De Benedetti A, Rhoads RE. Preferential translation of heat shock mRNAs in HeLa cells deficient in protein synthesis initiation factors-eIF-4E and eIF-4g. $\mathcal{F}$ Biol Chem 1992;267:21038-43.

20 Li GC, Laszlo A. Thermotolerance in mammalian cells: a possible role for HSPs. In: Atkinson BG, Walden DB, eds. Changes in eukaryotic gene expression in response to environmental stress. New York: Academic Press, 1985:227-54.

21 Ovelgönne H, van Wijk R. Modulation of HSP68 gene expression after heat shock in thermosensitized and thermotolerant cells is not solely regulated by binding of HSF to HSE. Int $\mathcal{F}$ Hyperthermia 1995;11:719-32.

22 Landry J, Chrétien P, Lambert H, et al. Heat shock resistance conferred by expression of the human HSP27 resistance conferred by expression of the hum

$23 \mathrm{Li} \mathrm{GC,} \mathrm{Li} \mathrm{L,} \mathrm{Liu} \mathrm{YK,} \mathrm{et} \mathrm{al.} \mathrm{Thermal} \mathrm{response} \mathrm{of} \mathrm{rat}$ fibroblasts stably transfected with the human $70-\mathrm{kDa}$ HSP-encoding gene. Proc Natl Acad Sci USA 1991;88: $1681-5$

24 Angelidis CE, Lazaridis I, Pagoulatos N. Constitutive expression of heat-shock protein 70 in mammalian cells confers thermoresistance. Eur f Biochem 1991;199:35-9.

25 Jäättelä $\mathrm{M}$, Wissing D, Bauer PA, et al. Major HSP hsp70 protects tumor cells from tumor necrosis factor cytotoxicity. EMBO f 1992;11/10:3507-12.

26 Parsell DA, Lindquist S. Heat shock proteins and stress tolerance. In: Morimoto RI, Tissières A, Georgopoulos C, eds. The biology of HSPs and molecular chaperones. Cold Spring Harbour: Cold Spring Harbour Laboratory Press, 1994:457-94.

27 Pusztai A, Ewen SWB, Grant G, et al. Relationship between survival and binding of plant lectins during small intestinal passage and their effectiveness as growth factors. Digestion 1990;46:308-16.

28 Pusztai A, Ewen SW, Grant G, et al. Antinutritive effects of wheat-germ agglutinin and other N-acetylglucosaminespecific lectins. Br $\mathcal{F}$ Nutr 1993;70:313-21.

29 Pusztai A, Grant G, Brown DS, et al. Lectins binding to the gut wall are growth factors for the pancreas: nutritional mplications for transgenic plants. In: Pusztai A, Bardocz S, eds. Lectins: Biomedical perspectives. London: Taylor and Francis, 1995:141-54.

30 Banwell JG, Howard R, Kabir I, et al. Small intestinal growth caused by feeding red kidney bean phytohemagglu-
tinin lectin to rats. Gasteroenterology 1993;104:1669-77.

31 Bardocz S, Grant G, Ewen SW, et al. Reversible effect of phytohaemagglutinin on the growth and metabolism of rat phytohaemagglutinin on the growth and meta

32 Pusztai A, Ewen SW, Grant G, et al. Lectins and also bacteria modify the glycosylation of gut surface receptors in the rat. Glycoconj f 1995;12:22-35.

33 Pusztai A, Koninkx J, Hendriks H, et al. Effect of the insecticidal Galanthus nivalis agglutinin on metabolism and the activities of brush border enzymes in the rat small intestine. f Nutr Biochem 1996;7:677-82

34 Hendriks HGCJM, Kik MJL, Koninkx JFJG, et al. Binding of kidney bean (Phaseolus vulgaris) isolectins to differentiated human colon carcinoma Caco-2 cells and their effect on cellular metabolism. Gut 1991;32:196-201.

35 Koninkx JFJG, Hendriks HGCJM, van Rossum JMA, et al. Interactions of legume lectins with the cellular metabolism of differentiated Caco-2 cells. Gastroenterology 1992;102: 1516-23.

36 Koninkx JFJG, Brown DS, Kok W, et al. Polyamine metabolism of enterocyte-like Caco-2 cells after exposure to Phaseolus vulgaris lectin. Gut 1996;38:47-52.

37 Draaijer M, Koninkx J, Hendriks, et al. Actin cytoskeletal lesions in differentiated human colon carcinoma Caco-2 cells after exposure to soybean agglutinin. Biol Cell 1989;65:29-35.

38 Kik MJ, Koninkx JF, van den Muysenberg A, et al. Pathological effects of Phaseolus vulgaris isolectins on pig jejunal mucosa in organ culture. Gut 1991;32:886-8.

39 Koninkx JFJG. Enterocyte-like Caco-2 cells as a tool to study lectin interaction. In: Pusztai A, Bardocz S, eds. Lectins: Biomedical perspectives. London: Taylor and Francis, 1995:81-101.

40 Lehr C-M, Kok W, Koninkx J. The effect of bioadhesive lectins on the barrier function of Caco-2 cell monolayers. Proc Int Symp Contr Release Bioact Mat 1994;21:344-5.

41 Bardocz S, Grant G, Brown DS, et al. Effect of fasting and refeeding on basolateral polyamine uptake and metabolism by the rat small bowel. Digestion 1991;50:28-35 
42 Peumans WJ, Stinissen HM, Carlier AR. Isolation and partial characterization of wheat-germ-agglutinin-like lectin from rye (Secale cereale) and barley
embryos. Biochem $\mathcal{7} 1982 ; 203: 239-43$.

43 Pusztai A Palmer R Nutritional evaluation of kidney bean Pusztai A, Palmer R. Nutritional evaluation of kidney bean
(Phaseolus vulgaris): the toxic principle. 7 Sci Food Agric 1977;28:620-3

44 Labarca C, Paigen K. A simple, rapid and sensitive DNA assay procedure. Anal Biochem 1980;102:344-52.

45 Jauregui HO, Hayner NT, Driscoll JL, et al. Trypan blue dye uptake and lactate dehydrogenase in adult rat hepatocytes - freshly isolated cells, cell suspensions, an primary monolayer cultures. In Vitro 1981;17:1100-10.

46 Laemmli UK. Cleavage of the structural proteins during the assembly of the head of bacteriophage T4. Nature 1970;277:680-5.

47 Peterson GL. A simplification of the protein assay method of Lowry et al. which is more generally applicable. Anal
Biochem 1977;83:346-56.

48 Hershey JWB. Translational control in mammalian cells. Anпu Rev Biochem 1991;60:717-55.

49 Lindegaard JC. Thermosensitization induced by step-down heating. Int $\mathcal{A}$ Hyperthermia 1992;8:561-86.

50 Ovelgönne $\mathrm{HH}$, Wiegant FAC, Souren JEM, et al. Enhancement of the stress response by low concentrations of arsenite in arsenite-pretreated Reuber $\mathrm{H} 35$ hepatoma cells. Toxi col Appl Pharmacol 1995;132:146-55.
51 Beck SC, Paidas CN, Mooney ML, et al. Presence of the stress-inducible form of hsp-70 (hsp-72) in normal rat stress-inducible form of hsp-70
colon. Shock 1995;3:398-402.

52 Hopwood D, Moitra S, Vojtesek B, et al. Biochemical analysis of the stress protein response in human oesophageal epithelium. Gut 1997;41:156-63.

53 Majecak DG, Luftig RB. Stabilization of actin filaments at early times after adenovirus infection and in heat-shocked cells. Virus Res 1991;19:31-45.

54 Koyasu S, Nishida E, Kadowaki T, et al. Two mammalian heat shock proteins, HSP90 and HSP100, are actinbinding proteins. Proc Natl Acad Sci USA 1986;83:8054-8.

55 Ferris DK, Harel-Ballen A, Morimoto RI, et al. Mitogen and lymphokine stimulation of heat shock proteins in $\mathrm{T}$ lymphocytes. Proc Natl Acad Sci USA 1988;85:3850-4.

56 Hansen LK, Houchins JP, O'Leary JJ. Differential regulation of HSC70, HSP70, HSP90 alpha, and HSP90 beta mRNA expression by mitogen activation and heat shock in human lymphocytes. Exp Cell Res 1991;192:587-96.

57 Haire RN, Petersons MS, O'Leary JJ. Mitogen activation induces synthesis of two heat-shock proteins in human induces synthesis of two heat-shock proter
lymphocytes. F Cell Biol 1988;106:883-91.

58 Deitsch EA, Beck SC, Cruz NC, et al. Induction of heat shock gene expression in colonic epithelial cells after incubation with Escherichia coli or endotoxin. Crit Care Med 1995;23:1371-6. 